\title{
Preliminary Phytochemical Screening, Quantitative Analysis of Alkaloids, and Antioxidant Activity of Crude Plant Extracts from Ephedra intermedia Indigenous to Balochistan
}

\author{
Rahman Gul, ${ }^{1,2,3}$ Syed Umer Jan,,4 Syed Faridullah, ${ }^{3}$ Samiullah Sherani, ${ }^{1}$ \\ and Nusrat Jahan ${ }^{3}$ \\ ${ }^{1}$ Faculty of Pharmacy, University of Balochistan, Quetta, Pakistan \\ ${ }^{2}$ Department of Health, Government of Balochistan, Quetta, Pakistan \\ ${ }^{3}$ Balochistan University of Information Technology, Engineering \& Management Sciences (BUITEMS), Quetta, Pakistan \\ ${ }^{4}$ College of Pharmacy, University of Texas at Austin, Austin, TX, USA \\ Correspondence should be addressed to Rahman Gul; gul.dotani@yahoo.com
}

Received 22 January 2017; Revised 19 February 2017; Accepted 23 February 2017; Published 13 March 2017

Academic Editor: Valdir Cechinel Filho

Copyright (C) 2017 Rahman Gul et al. This is an open access article distributed under the Creative Commons Attribution License, which permits unrestricted use, distribution, and reproduction in any medium, provided the original work is properly cited.

\begin{abstract}
The aim of this study was to evaluate the antioxidant activity, screening the phytogenic chemical compounds, and to assess the alkaloids present in the E. intermedia to prove its uses in Pakistani folk medicines for the treatment of asthma and bronchitis. Antioxidant activity was analyzed by using 2,2-diphenyl-1-picryl-hydrazyl-hydrate assay. Standard methods were used for the identification of cardiac glycosides, phenolic compounds, flavonoids, anthraquinones, and alkaloids. High performance liquid chromatography (HPLC) was used for quantitative purpose of ephedrine alkaloids in E. intermedia. The quantitative separation was confirmed on Shimadzu 10AVP column (Shampack) of internal diameter (id) $3.0 \mathrm{~mm}$ and $50 \mathrm{~mm}$ in length. The extract of the solute in flow rate of $1 \mathrm{ml} / \mathrm{min}$ at the wavelength $210 \mathrm{~nm}$ and methanolic extract showed the antioxidant activity and powerful oxygen free radicals scavenging activities and the IC50 for the E. intermedia plant was near to the reference standard ascorbic acid. The HPLC method was useful for the quantitative purpose of ephedrine (E) and pseudoephedrine (PE) used for 45 samples of one species collected from central habitat in three districts (Ziarat, Shairani, and Kalat) of Balochistan. Results showed that average alkaloid substance in E. intermedia was as follows: PE (0.209\%, 0.238\%, and $0.22 \%)$ and $\mathrm{E}(0.0538 \%, 0.0666 \%$, and $0.0514 \%)$.
\end{abstract}

\section{Introduction}

The importance of medicinal plant in drug development is known to us and humans have used them for different diseases from the beginning of human history [1]. Traditional folk treatment from wild plants has always guided researchers to search for novel medications to develop healthy life for humans and animals [2]. In addition, some medicinal plants are still obscured within the plant which need to be scientifically evaluated.

Ephedra (Ephedra intermedia) belongs to family Ephedraceae and is a genus of nonflowering plants, related to Gnetales, very near relatives of angiosperms [3]. Majority of the 50 Ephedra species throughout the world are adapted as a shrub to moisture and desert conditions [4-6]. Three species are found in Pakistan. E. intermedia shrubs are always green called Ma-Huang and, locally in Balochistan, they are called Oman. Ma-Huang (Ephedra) is resultant from the aerial parts of Ephedra sinica Stapf, E. intermedia Stapf, E. equisetina Bunge, and E. distachya L. It has been utilized medicinally as a stimulant, diaphoretic, and antiasthmatic $[7,8]$. It is a xerophytic shrub plant and grows in unfavorable soil and climatic conditions such as high temperature and high light (Figure 1) [9].

Most of the marketed drugs of Ephedra extracts are taken from the ephedrine and pseudoephedrine alkaloids present in many species shoots. The best recognized drug prepared from Ephedra is Ma-Huang utilized in Chinese drugs for the treatment of nasal congestion, fever, and asthma [10]. Ma-Huang is also used as a respiratory sedative and 


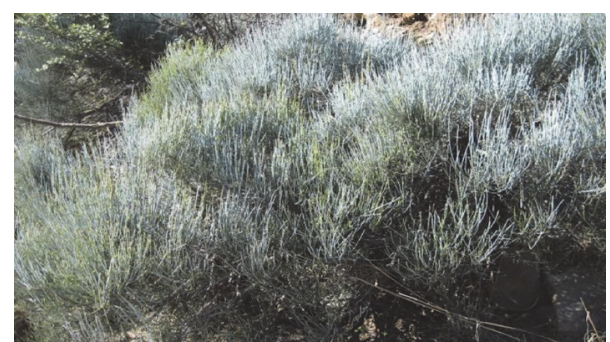

FIgURE 1: Ephedra intermedia plant.

cough treatment. Herbal mixture containing Ma-huang and combination products are widely available in health food stores. Many of these products are marketed as "diet pills" or "energy pills" or both [11]. Ma-Huang was traditionally gained from dried stem of E. equisetina, E. sinica, and $E$. intermedia [12] found in the region of Iran, Northwest India, and Pakistan (Balochistan). These shrub plants also showed antioxidant and antimicrobial activities [13-15]. Ephedra basic compounds consist of the alkaloids ephedrine and pseudoephedrine and phenols [16]. The stem consists of overall 1-3\% alkaloids, having ephedrine comprising 30-70\% of the total, depending on all the species and types of Ephedra plant. Ephedrine activates the CNS, increases the blood pressure, dilates the bronchial tubes, and increases the pulse rate. Pseudoephedrine is used for the relief of nasal congestion in its synthetic form [17-19]. HPLC method for the quantitative analysis [20] can give a baseline resolution of the alkaloids with the advantage of simple extraction and direct analysis of the alkaloids without derivatives: the reversed-phase HPLC method [21].

Balochistan is the largest and driest province of the country (about 35,000 sq km, i.e., $44 \%$ of the country's total area). It lies north to the tropics, between the latitude of 24 and 32 and between the longitudes of 60 to 70 East, with an area of about 134,000 square miles and a population of 140 million [22]. Thus, main purpose of this research work is to analyze the phytochemical screening and quantitative estimation of alkaloids and antioxidant activity of crude Ephedra extract.

\section{Material and Methods}

Aerial parts of Ephedra were collected in June to September 2015-2016 in five different places of Balochistan. All plants were growing at an altitude ranging from 600 to $1100 \mathrm{~m}$ over the sea level. These plants were identified at the herbarium section; a voucher specimen (E-RBT-04) has been deposited in the Department of Botany, University of Balochistan, Quetta, Pakistan.

Hydroalcohlic mixture was prepared by mixing two liters each of analytical grade ethanol, methanol and distilled water $7: 3$. the plant Ephedra was collected and cut into thin slices by minicing appratus. $2 \mathrm{~kg}$ of material was weighted and put into the brown glass bottle. Hydroalcholic mixture was added to it and macerated for one weak. The bottle was sealed with aluminium foil and kept in labortory at room temperature, and the bottle was shaken after 24 hours. Finally the filtrate was filtered through many layers of muslin cloth for coarse filtration. The coarse filtrate was than filtered through Whatman number 1 filter paper. The obtained filtrate was evaporated in a vacuum rotary evaporator under reduced pressure at $40^{\circ} \mathrm{C}$ until the filtrate was reduced to one-third of the starting filtrate volume. The obtained extracts were collected in stopper glass bottles and stored at $0^{\circ} \mathrm{C}$.

\section{Quantitative Analysis of the Alkaloids by HPLC}

A simple and rapid HPLC method was used for determination of alkaloids in different samples of Ephedra species by comparing it with the standards of ephedrine and pseudoephedrine. HPLC is valid method for the identification of ephedrine (E) and pseudoephedrine (PE) in Ephedra raw herbs. The pseudoephedrine and ephedrine calibration curve range in between 0.03125 to 5 microgram per milliliter. The calibration curve of the plant extract was made having regression coefficient of 0.9998 with different retention time. Different ephedrine alkaloids were eluted from the extracted Ephedra plant with $0.25 \mathrm{~mol} / \mathrm{H} 3 \mathrm{PO} 4$ water solution. The HPLC quantitative separation was confirmed on Shimadzu 10AVP column (Shampack) of internal diameter (id) $3.0 \mathrm{~mm}$ and $50 \mathrm{~mm}$ in length. The extract of the solute was in flow rate of $1 \mathrm{ml} / \mathrm{min}$ with mobile phase buffer solution $\mathrm{pH} 5.3$ and methanol and acetonitrile in ratio $1: 1: 8$. The recognition wavelength was put at $210 \mathrm{~nm}$. Reference standards for (-)ephedrine $\mathrm{HCl},(+)$-pseudoephedrine $\mathrm{HCl}$, and ascorbic acid were received from Merck Serono, Quetta Factory, and commercial market. All other reagents and chemicals were used of analytical grade.

3.1. Phytochemical Qualitative Analysis. The plant extracts and methanolic and ethanolic aqueous solutions were assessed for the existence of the phytochemical analysis by using the following standard methods [23-26].

3.1.1. Test for Anthraquinones. $10 \mathrm{ml}$ of benzene was added in $6 \mathrm{~g}$ of the Ephedra powder sample in a conical flask and soaked for 10 minutes and then filtered. Further $10 \mathrm{ml}$ of $10 \%$ ammonia solution was added to the filtrate and shaken vigorously for 30 seconds and pink, violet, or red color indicated the presence of anthraquinones in the ammonia phase.

3.1.2. Test for Tannins. $10 \mathrm{ml}$ of bromine water was added to the $0.5 \mathrm{~g}$ aqueous extract. Decoloration of bromine water showed the presence of tannins.

3.1.3. Test for Saponins. $5.0 \mathrm{ml}$ of distilled water was mixed with aqueous crude plant extract in a test tube and it was mixed vigorously. The frothing was mixed with few drops of olive oil and mixed vigorously and the foam appearance showed the presence of saponins. 


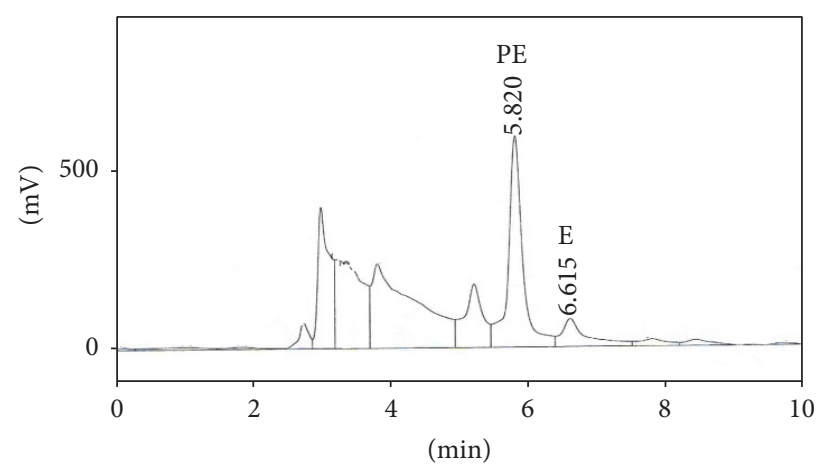

(a)

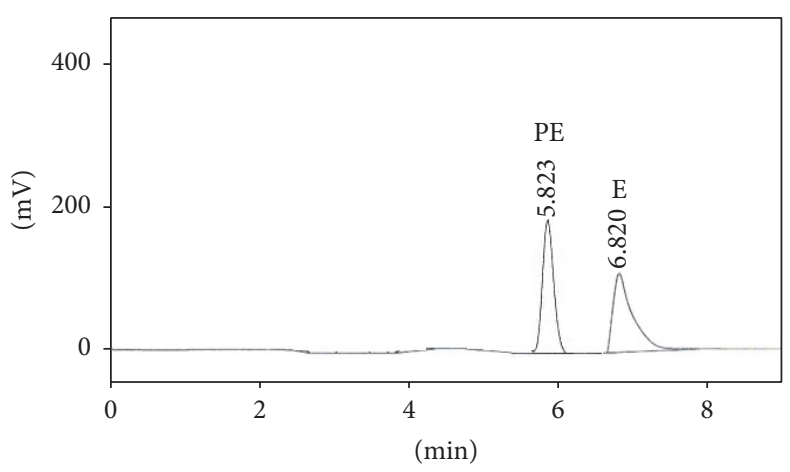

(b)

FIGURE 2: (a) Representative chromatograms of extracts from several E. intermedia containing (E) ephedrine and (PSE) pseudoephedrine. (b) Reference standard.

\subsubsection{Tests for Flavonoids}

Shinoda Test. Pieces of magnesium ribbon and Hcl concentrated were mixed with aqueous crude plant extarct after few minutes and pink color showed the presence of flavonoid.

Alkaline Reagent Test. $2 \mathrm{ml}$ of $2.0 \% \mathrm{NaOH}$ mixture was mixed with aqueous plant crude extract; concentrated yellow color was produced, which became colorless when we added 2 drops of diluted acid to mixture. This result showed the presence of flavonoids.

\subsubsection{Tests for Glycosides}

Liebermann's Test. We added $2.0 \mathrm{ml}$ of acetic acid and $2 \mathrm{ml}$ of chloroform with whole aqueous plant crude extract. The mixture was then cooled and we added $\mathrm{H}_{2} \mathrm{SO}_{4}$ concentrated. Green color showed the entity of aglycone, steroidal part of glycosides.

Keller-Kiliani Test. A solution of glacial acetic acid $(4.0 \mathrm{ml})$ with 1 drop of $2.0 \% \mathrm{FeCl}_{3}$ mixture was mixed with the $10 \mathrm{ml}$ aqueous plant extract and $1 \mathrm{ml} \mathrm{H}_{2} \mathrm{SO}_{4}$ concentrated. A brown ring formed between the layers which showed the entity of cardiac steroidal glycosides.

Salkowski's Test. We added $2 \mathrm{ml} \mathrm{H}_{2} \mathrm{SO}_{4}$ concentrated to the whole aqueous plant crude extract. A reddish brown color formed which indicated the presence of steroidal aglycone part of the glycoside.

3.1.6. Test for Terpenoids. $2.0 \mathrm{ml}$ of chloroform was added with the $5 \mathrm{ml}$ aqueous plant extract and evaporated on the water path and then boiled with $3 \mathrm{ml}$ of $\mathrm{H}_{2} \mathrm{SO}_{4}$ concentrated. A grey color formed which showed the entity of terpenoids.

3.1.7. Test for Steroids. $2 \mathrm{ml}$ of chloroform and concentrated $\mathrm{H}_{2} \mathrm{SO}_{4}$ were added with the $5 \mathrm{ml}$ aqueous plant crude extract. In the lower chloroform layer red color appeared that indicated the presence of steroids.

3.2. Antioxidant Activity. Method used for antioxidant activity was DPPH free radical scavenging assay.

3.2.1. DPPH Free Radical Scavenging Assay. To determine antioxidant activity 2,2-diphenyl-1-picryl-hydrezyl (DPPH) was used as free radical. $100 \mu \mathrm{M}$ concentration of DPPH was used in methanol. Serial dilutions were made to check the IC50. In 96-well micro plate total volume was $100 \mu \mathrm{l}$ which was consisting of $90 \mu \mathrm{l}$ of DPPH solution and $10 \mu \mathrm{l}$ of the test solution. The contents were mixed and incubated for 30 minutes at $37^{\circ} \mathrm{C}$. To determine the absorbance at $517 \mathrm{~nm}$ synergy HT BioTek USA micro plate reader was used. Ascorbic acid was used as standard antioxidant [27]. All readings were taken in triplicate. Ez-fit-5, Perrella Scientific Inc., Amherst, USA, software was used to calculate the IC50. Decrease in absorbance indicated increased radical scavenging activity which was determined by the following formula:

$$
\begin{aligned}
& \text { Inhibition (\%) } \\
& =\frac{(\text { abs. of control }- \text { abs. of test solution }) \times 100}{\text { Abs. of control }},
\end{aligned}
$$

where absorbance of control = total radical activity without inhibitor and absorbance of test $=$ activity in the presence of test compounds.

\section{Results and Discussion}

The HPLC analysis explained here was shown to be a correct and accurate technique for the illustration of $\mathrm{E}$ and $\mathrm{PE}$ in $E$. intermedia. Although liquid chromatographic techniques for quantitating ephedrine alkaloids in simple Ephedra herb have been explained previously [28].

A distinctive HPLC chromatogram for standard solution of $\mathrm{E}$ and $\mathrm{PE}$ is shown in Figure 2. Retention times examined 
TABLE 1: Contents of two alkaloids in 45 Ephedra samples derived from the E. intermedia in (500 mg powder).

\begin{tabular}{|c|c|c|c|c|c|}
\hline Collection place & $\mathrm{PE}$ & $\mathrm{E}$ & Total & PE/total & E/total \\
\hline Ziarat (Warchum) & 1.318 & 0.017 & 1.335 & 0.98727 & 0.01273 \\
\hline Ziarat (Warchum) & 1.026 & 0.283 & 1.309 & 0.7838 & 0.2162 \\
\hline Ziarat (Warchum) & 1.163 & 0.351 & 1.514 & 0.76816 & 0.23184 \\
\hline Ziarat (Warchum) & 1.173 & 0.334 & 1.507 & 0.77837 & 0.22163 \\
\hline Ziarat (Warchum) & 0.645 & 0.046 & 0.691 & 0.93343 & 0.06657 \\
\hline Ziarat (Warchum) & 0.795 & 0.136 & 0.931 & 0.85392 & 0.14608 \\
\hline Ziarat (Warchum) & 1.173 & 0.305 & 1.478 & 0.79364 & 0.20636 \\
\hline Ziarat (Kawas) & 1.307 & 0.263 & 1.57 & 0.83248 & 0.16752 \\
\hline Ziarat (Kawas) & 1.316 & 0.304 & 1.62 & 0.81235 & 0.18765 \\
\hline Ziarat (Kawas) & 1.289 & 0.32 & 1.609 & 0.80112 & 0.19888 \\
\hline Ziarat (Kawas) & 1.433 & 0.392 & 1.825 & 0.78521 & 0.2148 \\
\hline Ziarat (Kawas) & 1.415 & 0.401 & 1.811 & 0.78133 & 0.2214 \\
\hline Ziarat (Proper) & 1.393 & 0.376 & 1.769 & 0.78745 & 0.21255 \\
\hline Ziarat (Proper) & 1.411 & 0.404 & 1.815 & 0.77741 & 0.22259 \\
\hline Ziarat (Proper) & 1.381 & 0.363 & 1.744 & 0.79186 & 0.20814 \\
\hline Ziarat (Proper) & 1.379 & 0.355 & 1.734 & 0.79527 & 0.20473 \\
\hline Ziarat (Warchum) & 0.613 & 0.183 & 0.796 & 0.7701 & 0.2299 \\
\hline Ziarat (Warchum) & 0.546 & 0.143 & 0.689 & 0.79245 & 0.20755 \\
\hline Ziarat (Warchum) & 0.597 & 0.18 & 0.777 & 0.76834 & 0.23166 \\
\hline Ziarat (Warchum) & 1.118 & 0.049 & 1.167 & 0.95801 & 0.04199 \\
\hline Ziarat (Warchum) & 1.119 & 0.198 & 1.317 & 0.84966 & 0.15034 \\
\hline Ziarat (Kawas) & 0.873 & 0.217 & 1.09 & 0.80092 & 0.19908 \\
\hline Ziarat (Kawas) & 1.0996 & 0.382 & 1.4816 & 0.74217 & 0.25783 \\
\hline Ziarat (Kawas) & 1.0992 & 0.38 & 1.4792 & 0.7431 & 0.2569 \\
\hline Ziarat (proper) & 1.099 & 0.374 & 1.473 & 0.7461 & 0.2539 \\
\hline Ziarat (proper) & 0.867 & 0.28 & 1.147 & 0.75589 & 0.24412 \\
\hline Ziarat (proper) & 0.859 & 0.22 & 1.079 & 0.79611 & 0.20389 \\
\hline Ziarat (proper) & 0.843 & 0.227 & 1.07 & 0.78785 & 0.21215 \\
\hline Ziarat (proper) & 1.374 & 0.332 & 1.706 & 0.80539 & 0.19461 \\
\hline Shairani & 1.226 & 0.262 & 1.488 & 0.823 & 0.176 \\
\hline Shairani & 0.873 & 0.222 & 1.095 & 0.797 & 0.202 \\
\hline Shairani & 1.007 & 0.403 & 1.41 & 0.714 & 0.285 \\
\hline Shairani & 0.993 & 0.399 & 1.392 & 0.713 & 0.286 \\
\hline Shairani & 0.996 & 0.468 & 1.464 & 0.68 & 0.319 \\
\hline Shairani & 1.49 & 0.313 & 1.803 & 0.826 & 0.173 \\
\hline Shairani & 1.475 & 0.307 & 1.782 & 0.827 & 0.172 \\
\hline Shairani & 1.466 & 0.295 & 1.761 & 0.832 & 0.167 \\
\hline Kalat (Harboi) & 1.009 & 0.179 & 1.188 & 0.849 & 0.1506 \\
\hline Kalat (Harboi) & 1.374 & 0.346 & 1.72 & 0.798 & 0.2011 \\
\hline Kalat (Harboi) & 1.514 & 0.32 & 1.834 & 0.825 & 0.1744 \\
\hline Kalat (Harboi) & 1.106 & 0.195 & 1.301 & 0.85 & 0.1498 \\
\hline Kalat (Harboi) & 1.188 & 0.217 & 1.405 & 0.845 & 0.1544 \\
\hline Kalat (Harboi) & 0.87 & 0.274 & 1.144 & 0.76 & 0.2395 \\
\hline Kalat (Harboi) & 0.867 & 0.264 & 1.131 & 0.766 & 0.2334 \\
\hline Kalat (Harboi) & 0.872 & 0.266 & 1.138 & 0.766 & 0.2337 \\
\hline
\end{tabular}

for PE and $\mathrm{E}$ were between about 5.82 and 6.82 minutes. Relative retention times for each alkaloid were 5.7 and 6.61 minutes.
When extracted independently, no chromatographic interference was observed for any of the extra ingredients explained in Table 1. 
TABLE 2: Recovery and SD of E and PE of studied samples. $n=45$.

\begin{tabular}{|c|c|c|c|c|c|c|}
\hline \multirow{2}{*}{ Area } & \multicolumn{3}{|c|}{$\mathrm{PE}$} & \multicolumn{3}{|c|}{$E$} \\
\hline & Mean & $\mathrm{SD}$ & Recovery\% & Mean & $\mathrm{SD}$ & Recovery\% \\
\hline Ziarat, $n=29$ & 1.093 & 0.276 & 0.2186 & 0.269 & 0.1129 & 0.0538 \\
\hline Shairani, $n=8$ & 1.190 & 0.256 & 0.238 & 0.333 & 0.0821 & 0.0666 \\
\hline Total, $n=45$ & 1.112 & 0.0155 & 0.222 & 0.278 & 0.0275 & 0.0204 \\
\hline
\end{tabular}

The optimized technique was performed to the HPLC analysis of $45 \mathrm{E}$. intermedia samples. Ephedra herb was collected in three regions of Ziarat, one region of Sherani, and two regions of Kalat. The information on $\mathrm{E}$ and $\mathrm{PE}$ content in these samples is discussed in Table 1.

The outcome or result demonstrated that the whole quantity of these two alkaloids were not considerably different among the species, but the ratio pattern of the alkaloid content was established to be helpful in classifying the samples resulting from this Ephedra species. The average recovery of pseudoephedrine is as follows: Ziarat $0.2186 \%$, Sherani $0.238 \%$, and Kalat $0.2255 \%$ and in the same solution the recovery of Ephedrine in Ziarat was $0.0538 \%$, in Sherani was $0.0666 \%$, and in Kalat was $0.0514 \%$ and the relative standard deviation for each active substance was also calculated. The result was summarized in Table 2.

The results in tables show excellent recovery of PE from its solution and very low adsorption of E. High recoveries of PE were obtained due to its higher polarity and solubility that provided a strong interaction with orthophosphoric acid allowing it to remain in the aqueous solution. However, the loss of E might be caused due to its lower polarity and less quantity in Ephedra Herba.

The consequences illustrated that the whole quantity of these two alkaloids did not considerably vary among the samples. But the ratio pattern of the alkaloids content was originated to be helpful in recognizing the samples resulting from these Ephedra species and the ratio pattern was extra precise compared to that accounted before [29]. The results of this study confirm the results of a previous study [30]. The ratio E/total alkaloids was created to be extremely helpful in totally recognizing E. intermedia (ratio $<0.31$, for all samples). Hong et al. [30] stated the ratio for $E$. intermedia was $<3.2$. We employed this rule to recognize the species of Ephedra using the alkaloid content data accounted by other scientists [28, 29]. The results illustrated that more than $95 \%$ of the Ephedra herb samples resulting from the one Ephedra plant could be recognized accurately.

4.1. Phytochemical Analysis for the Methanolic and Ethanolic Extract of Ephedra intermedia. The detailed methods are described above and the results are also given in Table 3.

4.2. Antioxidant Activity Using Ascorbic Acid as Standard Equivalent. The methanolic extract free radical scavenging activity of Ephedra intermedia has been tested by DPPH radical procedure using ascorbic acid as a reference standard.
TABle 3: Phytochemical analysis for the methanolic and ethanolic extract of E.intermedia.

\begin{tabular}{lcc}
\hline $\begin{array}{l}\text { Phytochemical } \\
\text { compounds }\end{array}$ & Methanolic extract & Ethanolic extract \\
\hline Cardiac glycosides & + & + \\
Saponin glycoside & - & - \\
Alkaloids & + & + \\
Amino acids & - & - \\
Starch & - & - \\
Reducing sugars & + & + \\
Phenols & + & + \\
Volatile oil & - & - \\
Tannin & - & - \\
Flavonoids & + & + \\
Steroids & - & + \\
\hline
\end{tabular}

$+=$ presence; $-=$ absent .

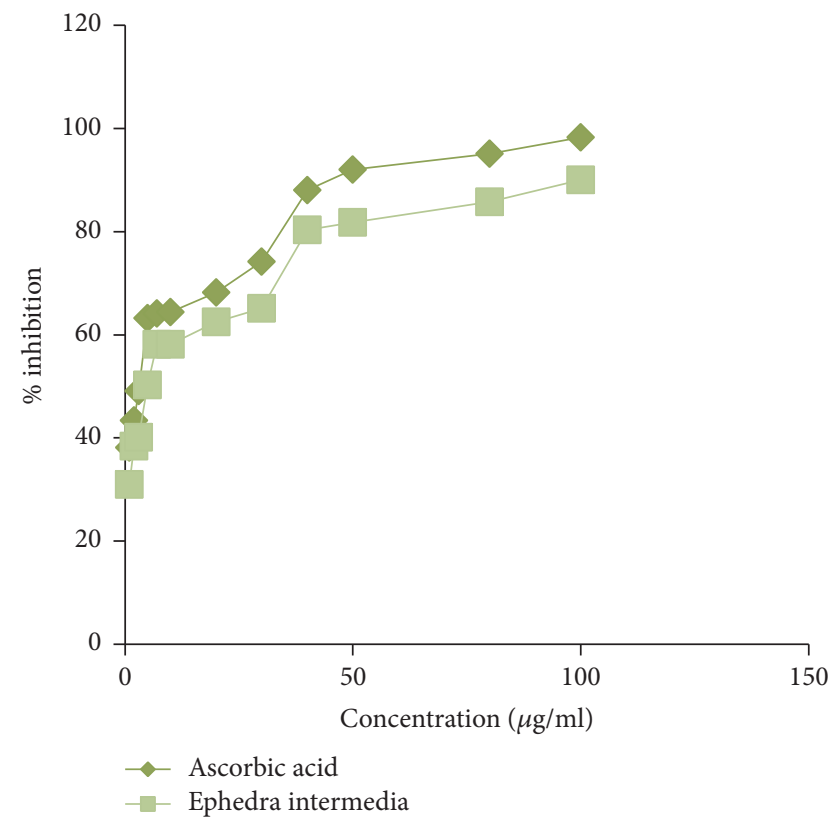

FIgURE 3: \% inhibition of ascorbic acid standard and Ephedra intermedia extract.

The concentration ranged from 1 to $100 \mu \mathrm{g} / \mathrm{ml}$. The zero inhibition was measured for the solution which contained only DPPH without any aqueous plant extract. The results are showed in Table 4 and the data readings are explained in Figure 3. 
TABLE 4: Percentage inhibition activity for ascorbic acid and E. intermedia.

\begin{tabular}{lcc}
\hline Concentration $\mu \mathrm{g} / \mathrm{ml}$ & \% inhibition by ascorbic acid \pm SD & \% inhibition by Ephedra intermedia \pm SD \\
\hline 1 & $38.15 \pm 1.01$ & $30.94 \pm 1.01$ \\
2 & $43.35 \pm 1.14$ & $38.38 \pm 1.12$ \\
3 & $49.09 \pm 1.09$ & $40.09 \pm 1.18$ \\
5 & $63.19 \pm 1.11$ & $50.29 \pm 0.76$ \\
7 & $64.10 \pm 1.03$ & $58.16 \pm 1.11$ \\
10 & $64.38 \pm 1.11$ & $58.16 \pm 1.33$ \\
20 & $68.19 \pm 2.11$ & $62.46 \pm 1.35$ \\
30 & $74.21 \pm 1.13$ & $65.17 \pm 1.71$ \\
40 & $88.10 \pm 1.50$ & $80.36 \pm 1.22$ \\
50 & $92.01 \pm 1.10$ & $81.83 \pm 1.49$ \\
80 & $95.12 \pm 1.22$ & $85.83 \pm 1.01$ \\
\hline
\end{tabular}

\section{Conclusion}

The phytochemical analysis showed that the Ephedra intermedia plant extract contains a mixture of phytochemicals as reducing sugars, cardiac glycoside, phenolic compounds, flavonoids, and alkaloids. The quantitative DPPH assay indicated that the plant extract has potent antioxidant activity which can be an excellent option for biological and chemical analysis and can be further subjected for the isolation of the therapeutically active compounds and the alkaloid content of PE in E. intermedia of Shairani (average $1.524 \mathrm{mg} / 500 \mathrm{mg}$ ) was higher than that in E. intermedia of Ziarat (average $1.36 \mathrm{mg} / 500 \mathrm{mg}$ ) and E. intermedia of Kalat (average $1.35 \mathrm{mg} / 500 \mathrm{mg}$ ), but the changeable range of total alkaloid content of each Ephedra was so broad that the whole alkaloid content ranges of these collected samples species really overlap, which cannot affect the claim that these Ephedra species should be analyzed as dissimilar drugs. The contents of $\mathrm{PE}$ and $\mathrm{E}$ are also pretty different between the samples of E. intermedia. In this study we utilized the method for the recognition of $E$. intermedia by means of the ratio E/total alkaloids. Since these samples are not surely different in alkaloid contents of $\mathrm{E} / \mathrm{PE}$ as well, this method of study is an excellent choice and can be further subjected for the isolation of therapeutically active substance with antiasthmatic and antioxidant potency.

\section{Conflicts of Interest}

The authors declare that they have no conflicts of interest.

\section{Acknowledgments}

The author's would like to thank the Higher Education Commission of Pakistan for fee reimbursement, Health Department Government of Balochistan (for study leave), Dean, Department of Pharmacy, The Islamia University of Bahawalpur, and Dean, Department of Pharmacy, UOB, for their support in research.

\section{References}

[1] N. Fransworth, The Role of Ethanopharmacology in Drug Development. Bioactive Compounds from Plant, John Wiley \& Sons, 2008.

[2] J. Achterberg, Imagery in Healing Shamanism and Modern Medicine, Shambhala Publications, Boulder, Colo, USA, 2013.

[3] W. E. Friedman, "The evolution of double fertilization and endosperm: an 'historical' perspective," Sexual Plant Reproduction, vol. 11, no. 1, pp. 6-16, 1998.

[4] H. H. W. Pearson, Gnetales, Cambridge University Press, London, UK, 1929.

[5] J. Stevens, "The Ephedra story," Application Note, vol. 215, pp. $1-6,2003$.

[6] S. Caveney, D. A. Charlet, H. Freitag, M. Maier-Stolte, and A. N. Starratt, "New observations on the secondary chemistry of world Ephedra (Ephedraceae)," American Journal of Botany, vol. 88, no. 7, pp. 1199-1208, 2001.

[7] T. K. Huang, Handbook of Composition and Pharmacological Action of Commonly-Used Traditional Chinese Medicine (II), Chinese Medicine Technology Pres, Beijing, China, 1994.

[8] D. Bensky and A. Gamble, Chinese Herbal Medicine Materia Medica, Eastland Press, Seatle, Wash, USA, 1986.

[9] H. Freitag and M. Maier-Stolte, "The Ephedra-species of P. Forsskal: identity and typification," Taxon, vol. 38, no. 4, pp. 545-556, 1989.

[10] Y. P. Zhu, Chinese Materia Medica: Chemistry, Pharmacology and Applications, Harwood Academic, Amsterdam, The Netherlands, 1998.

[11] L. M. White, S. F. Gardner, B. J. Gurley, M. A. Marx, P.-L. Wang, and M. Estes, "Pharmacokinetics and cardiovascular effects of ma-huang (Ephedra sinica) in normotensive adults," Journal of Clinical Pharmacology, vol. 37, no. 2, pp. 116-122, 1997.

[12] N. A. Qazilbach, "Pakistan Ephedra," Pharmacologische Weekblad, vol. 106, pp. 345-349, 1971.

[13] A. Parsaeimehr, E. Sargsyan, and K. Javidnia, "A comparative study of the antibacterial, antifungal and antioxidant activity and total content of phenolic compounds of cell cultures and wild plants of three endemic species of Ephedra," Molecules, vol. 15, no. 3, pp. 1668-1678, 2010.

[14] S. Bagheri-Gavkosh, M. Bigdeli, M. Shams-Ghahfarokhi, and M. Razzaghi-Abyaneh, "Inhibitory effects of Ephedra major 
Host on Aspergillus parasiticus growth and aflatoxin production," Mycopathologia, vol. 168, no. 5, pp. 249-255, 2009.

[15] J. L. Hollander and S. B. V. Wall, "Dispersal syndromes in North American Ephedra," International Journal of Plant Sciences, vol. 170, no. 3, pp. 323-330, 2009.

[16] M. A. M. Nawwar, H. H. Barakat, J. Buddrust, and M. Linscheidt, "Alkaloidal, lignan and phenolic constituents of Ephedra alata," Phytochemistry, vol. 24, no. 4, pp. 878-879, 1985.

[17] M. Ganzera, C. Lanser, and H. Stuppner, "Simultaneous determination of Ephedra sinica and Citrus aurantium var. amara alkaloids by ion pair chromatography," Talanta, vol. 4, pp. 889894, 2005.

[18] A. Inoko, N. Kakiuchi, M. Yoshimitsu, S. Cai, and M. Mikage, "Ephedra resource in Sichuan and Yunnan Provinces 2007," Biological and Pharmaceutical Bulletin, vol. 32, no. 9, pp. 16211623, 2009.

[19] Y. Kitani, S. Zhu, T. Omote et al., "Molecular analysis and chemical evaluation of Ephedra plants in Mongolia," Biological and Pharmaceutical Bulletin, vol. 32, no. 7, pp. 1235-1243, 2009.

[20] C. Imaz, D. Carreras, R. Navajas et al., "Determination of ephedrines in urine by high-performance liquid chromatography," Journal of Chromatography A, vol. 631, no. 1-2, pp. 201-205, 1993.

[21] M. J. Yang and T. Y. Wang, "Studies on the quality of Chinese drugs Ma-Haung," Journal of Ningxia University (Natural Science Edition), vol. 20, pp. 70-71, 1999.

[22] "Federal Bureau of Statistics Pakistan," 2004, http://www.pbs .gov.pk/publications.

[23] O. O. Debiyi and F. A. Sofowora, "Pytochemical screening of medical plants,” Iloyidia, vol. 3, pp. 234-246, 1978.

[24] T. S. Roopashree, R. Dang, R. H. S. Rani, and C. Narendra, "Antibacterial activity of antipsoriatic herbs: Cassia tora, Momordica charantia and Calendula officinalis," International Journal Applied Research in Natural Products, vol. 1, no. 3, pp. 20-28, 2008.

[25] A. Sofowora, Phytochemical Screening of Medicinal Plants and Traditional Medicine in Africa, Spectrum Books Ltd, Ibadan, Nigeria, 1993.

[26] G. E. Trease and W. C. Evans, "Phenols and phenolic glycosides," in Textbook of Pharmacognosy, vol. 12, pp. 343-383, Balliese, Tindall and Co Publishers, London, UK, 1989.

[27] R. Jamous, S. Zaitoun, A. Husein, I. Qasem, and M. Ali-Shtayeh, "Screening for biological activities of medicinal plants used in traditional arabic palestinian herbal medicine," European Journal of Medicinal Plants, vol. 9, no. 1, pp. 1-13, 2015.

[28] K. Sagara, T. Oshima, and T. Misaki, "A simultaneous determination of norephedrine, pseudoephedrine, ephedrine and methylephedrine in Ephedrae Herba and oriental pharmaceutical preparations by ion-pair high-performance liquid chromatography," Chemical and Pharmaceutical Bulletin, vol. 31, no. 7, pp. 2359-2365, 1983.

[29] Y.-M. Liu, S.-J. Sheu, S.-H. Chiou, H.-C. Chang, and Y.-P. Chen, "A comparative study on commercial samples of Ephedrae herba," Planta Medica, vol. 59, no. 4, pp. 376-378, 1993.

[30] H. Hong, H.-B. Chen, D.-H. Yang et al., "Comparison of contents of five ephedrine alkaloids in three official origins of Ephedra Herb in China by high-performance liquid chromatography," Journal of Natural Medicines, vol. 65, no. 3-4, pp. 623-628, 2011. 

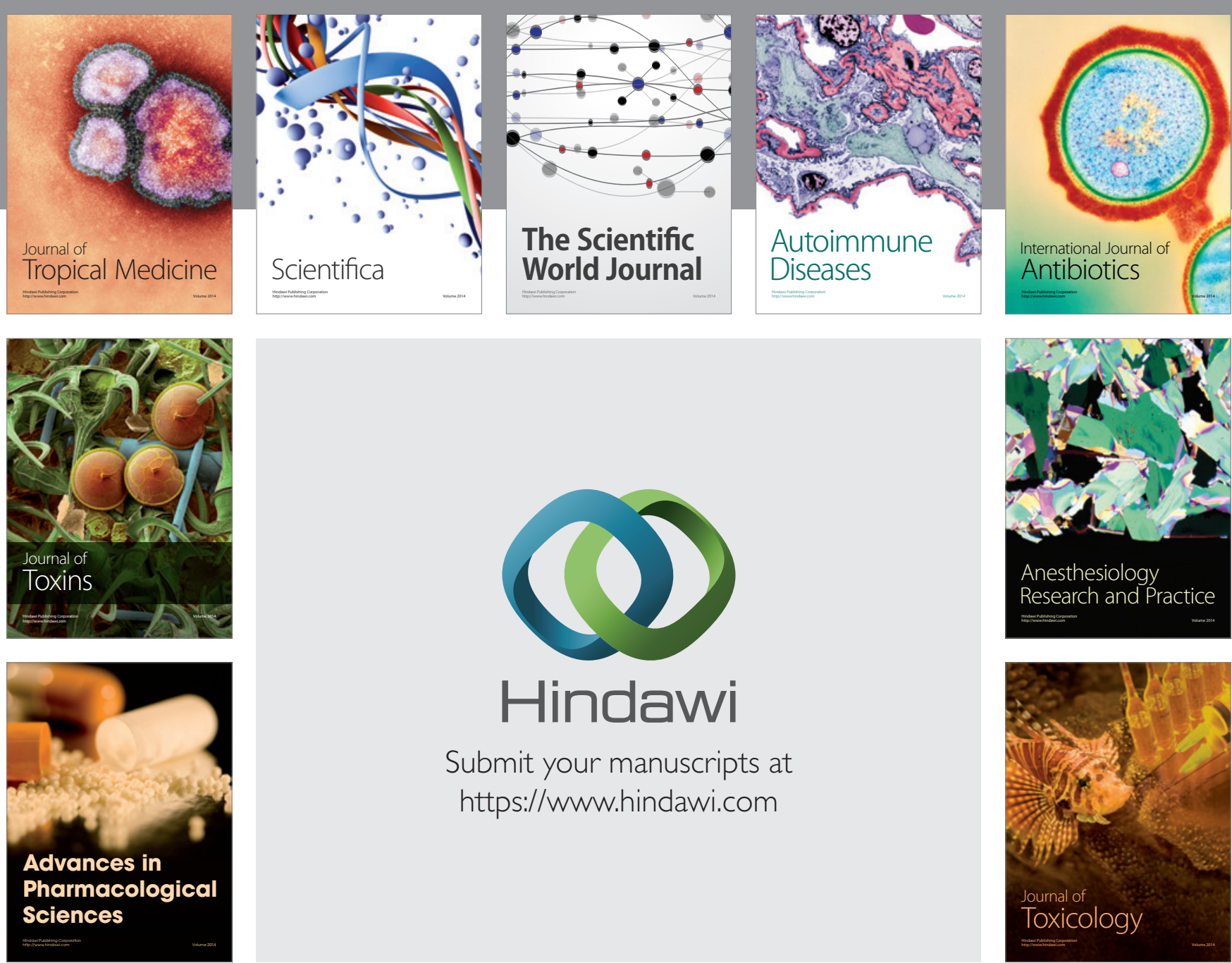

\section{Hindawi}

Submit your manuscripts at

https://www.hindawi.com
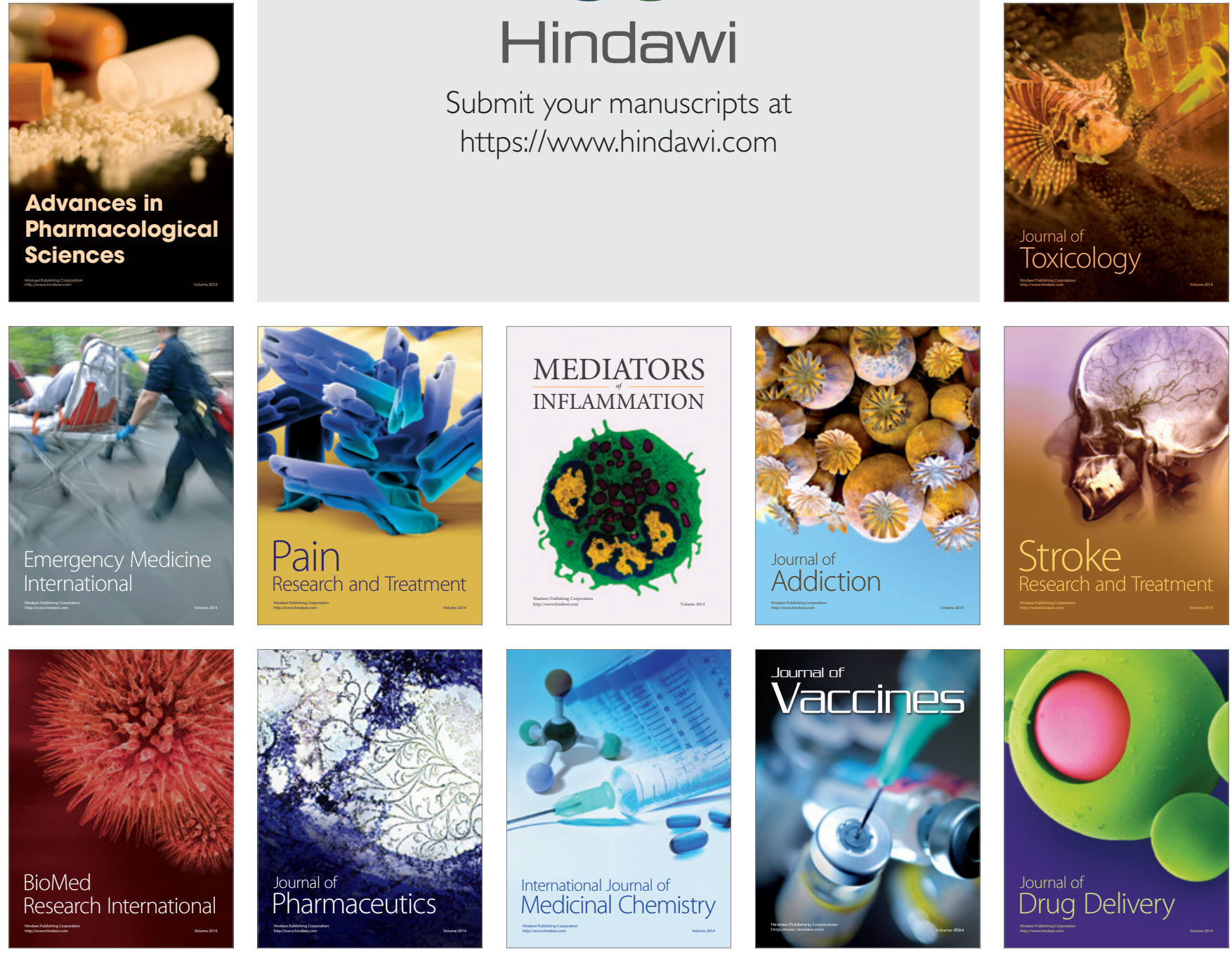